\title{
PRELIMINARY NOTE ON THE NERVOUS SYSTEM OF THE GENUS CYPRIS.
}

\section{[With Plates III and $I V \cdot]$ \\ By C. H. Turner.}

Some time ago I began to collect material for a study of the histology of the Ostracoda. The work is progressing, but, owing to delays in obtaining material, it will be a year or more before the work is completed. This being the case and since, so far as I have been able to discover, no work has been published on the histological neurology of the fresh-water Ostracoda, it is thought that a preliminary note on the nervous system of Cypris will not be an unwelcome contribution to Biology. Since it is intended, in the final paper, to give a resumé of all the histological papers that have been published on the Ostracoda, no bibliographical list is given in this note: however, comparisons will be made between the nervous system of Cypris and that of the other forms that have been described. For a similar reason, it is not considered necessary to give an account of the technique involved. The following remarks are based chiefly on a study of Cypris herricki, but sections of other members of the genus have been used for comparison.

The nervous system of Cypris agrees with that of other crustacea in being composed of a compound supra-œsophageal ganglion and a multi-ganglionic ventral chain.

The supra-œsophageal ganglion [fig. 9] or brain lies much nearer the dorsal than than the ventral surface of the body and lies cephalad of the foregut. This is a compound structure, being composed of at least three sets of ganglia. These sets are: the optic ganglion, the antennulary ganglia and the cere- 
bral ganglia. The optic ganglion occupies the dorso-cephalic portion of the brain. It is a median unpaired structure, but its histology seems to indicate that the ganglion has been formed by the fusion of three ganglia. From the apex of the optic ganglion, which is also the apex of the brain, a single median nerve [fig. Io] arises. This is the optic nerve. After passing dorsad a short distance this nerve separates into three branches - one branch for each division of the tripartite median eye [fig. 2] The antennulary ganglia occupy the lateral portions of the brain. From each of these ganglia a nerve arises [fig. Io] which passes latero-cephalad to the antennule of the same side. Near the meson, but ventrad of the optic ganglion, there is a pair of ganglia. These I have considered the cerebral ganglia. There is a commissural connection between the two halves of the supra-œsophageal ganglia ; but nothing has been discovered that would lead one to suppose that the norves decussate within the brain.

The brain is connected with the ventral chain by two circumcesophageal commissures. These are not true commissures, for about midway between the brain and the ventral chain each commissure contains a ganglion. This is the antennary ganglion. The antennary nerve [Fig. 3, 8] of each side leaves the corresponding circum-œsophageal commissure immediately behind the brain. A few of the fibres of this ncrve arise in the brain, the remainder arise in the antennary ganglion.

As far as I have been able to ascertain what is known about the ventral chain of the Ostracoda may be summarized in the following words of Professor Lang": "The ventral cord of Cythere which follows the brain and osophageal commissures is said to consist of an infra-cesophageal ganglion and of four subsequent ventral ganglia. The infra-cesophageal ganglion is said to show its composition out of two ganglia and to innervate the jaws, while the three subsequent ganglia give off nerves to the limbs, and the last ganglion nerves to the most posterior divisions of the body and the genital apparatus. p. 344 .

1Text book of Comparative Anatomy. Trans. by H. Bernard. ISgr, Vol. I, 
In contrast with the above, the ventral chain of Halocypris appears much concentrated. It consists of an infra-œesophageal ganglion with nerves to the jaws and maxillipedes, and a small ventral ganglion. Out of the latter arise two pairs of nerves, which probably innervate the musculature of the limbs and the abdomen."

Morphologically the ventral chain of Cypris herricki Turner, is intermediate between these two extremes. It is more concentrated than that of Cythere but not quite so compact as that of Halocypris. In this case the ventral chain consists of an infra-oesophageal ganglion and two subsequent ventral ganglia. All these ganglia are connected not only by two longitudinal commissures, [fig. 7] which extend throughout the chain, but also by straggling chains of cells [fig. 9].

The infra-œsophageal ganglion is compounded out of three pairs of ganglia and innervates the jaws and maxillae. Three transverse commissures can be demonstrated in this compound ganglion corresponding to its three pairs of nerves; viz. the mandibular and the two maxillary nerves. The mandibular nerve arises in the cephalic portion of the infra-œsophageal ganglion. It passes forward into the circum-œesophageal commissure for a short distance and then passes laterad to the mandible. [fig. 3] A short distance caudad of the mandibular nerve the first maxillary nerve leaves the infra-œsophageal ganglion and passes laterad to the first maxilla. [ftg. 7] Still further caudad the second maxillary nerve leaves the infra-œsophageal ganglion and passes latero-caudad to the second maxilla. [fig. 7] In addition to these nerves, in some of my sections I have observed what appears to be a nerve passing to the digestive tract. If this be a nerve (which I doubt) it may be a representative of the sympathic system.

The two ganglia which follow the infra-œesophageal ganglion correspond to the two pair of legs which follow the maxillæx. From the lateral borders of each ganglion nerves pass to the corresponding pair of legs. In addition to this, from the last ganglion a prominent tract passes caudad to innervate the posterior portion of the body and the post-abdomen. As this tract 
nears the caudal portion of the body it becomes more and more attenuated. This attenuation is probably due to the giving off of nerves to the neighborlng parts.

The entrance to the mouth of these creatures is fringed with hairs. These hairs, I am inclined to think, function as sensory setae. This view is supported by the fact that these hairs rest upon a layer of elongated cells [fig. 4] which have, in well stained preparations, large clear nuclei and small densely colored nucleoli-cells that are innervated by the intra-œsophageal ganglion and whose general appearance indicates that they are nervous in function.

The most conspicuous sense organ of the genus $C_{y p}$ ris is the eye. This is a tripartite structure [fig. 2]. It consists of a median and two lateral portions. The median portion lies further ventrad than the two lateral. The space between these three portions is liberally supplied with pigment. Each of the three divisions of this so-called pigment spot is multicellular. In the lateral portions the cells are as long as the structure is wide, and they are arranged with their longitudinal axes perpendicular to that section of the eye. In the median portion the cells are arranged radially. The median eye of the Copepoda, according to Grenacher, is, in all essentials, similar to the eye above described. In describing that eye, Lang ${ }^{1}$ considers the three divisions to be retinal cells. In that connection he says, in describing the tripartite eye of Calanella mediterranea: "Each single eye is composed of a pigment cup and a strongly refractive transparent 'lens' laid in and on it. The term lens is, however, not applicable. It is composed of several cells, each of which is connected, whether at its outer or inner side is not yet certain, with a fibre of the optic nerve, and must, therefore be considered as a retinal cell."

In Cypris herricki the nerve fibres are united to the outer ends of the cells. This agrees with what Dr. Claus found to be

\footnotetext{
IOp. cit., p. $35^{2}$.
} 
the case in the median eyes of the Copepoda, Cladocera and Ostracoda investigated by him. ${ }^{1}$

Since the publication of the paper ${ }^{2}$ in which O. Bütschli attempts to show how the lateral eyes of the vertebrates may have been derived from the median tripartite eye of Salpa, this tripartite eye, which is of almost universal occurence among the entomostraca, becomes enhanced in interest. One at once begins to speculate on the possibility of this median tripartite eye of the entomostraca becoming transformed into the lateral eyes of the crustacea. Indeed, Dr. Claus, in his late work, ${ }^{3}$ has already stated that the lateral eyes of the Corycaeidæe are laterally rotated portions of the median eyes. In this connection it may be of interest to quote a portion of Dr. Giesbrecht's resume of Dr. Claus' paper: “Die Seitenaugen der Corycaeiden sind abgerückte Theile des medianauges, diejenigen der Pontelliden entsprechen dagegen dem zusammengesetzten Arthropodenauge, während ihr ventrales Auge ein dreitheiliges medianauge dürfte ebenso wie die beiden frontalen Sinnesorgane der ersten anlage nach auf Zellengruppen der Scheitelplatte, von der aus wir, . . . die obern Schlundganglien der gliederthiere abzuleiten haben, zu beziehen sein; die drei Augentheile sind vielleicht mit den drei Punktaugen an der Scheitelplatte von Annelidenlarven phylogenetisch in Beziehung zu bringen; die Lage ihrer Pigmentzellen und ihre inverse Form werden auf eine convergent nach einem Punkte gerichtete Drehung zurückgeführt, welche mit dem Herabrücken des Organs in die Tiefe verbunden war: die Secret und Cornealinsen werden von Hypodermiszellen abgeschieden, ähnlich wie Krystallkegel und Corneafacette des zusammengestzten auges: das auge besitzt eine mesodermal Hülle, die sich in das neurilemm

${ }^{1}$ C. Claus. Ueber die feineren Bau des Medianauges der Crustaceen. Anzeiger Akad. Wien. I891, pp. 124-127. Ref. in Zool. Jahresbericht für 1891, Arthropoda 29.

${ }^{2}$ Einige Bemerkungen Ueber die Augen der Salpen, Zool. Anzeigcr, XV, Jahrg., 349 .

${ }^{3} \mathrm{Op}$ cit. 
des Opticus fortsetzt: Dic function des medienauges war ursprünglich, das Thier bezüglich der Richtung der Lichtquelle zu orientiren; bei complicirterem Bau, schon bei den Calaniden, hat es wahrscheinlich auch die Fähigkeit einer beschränkten Bildperception. Am medianauge der malakostrakenlarven ist der ventral Becher bisher nicht beobachtet, aber wohl auch vorhanden."

In a Cypris obtained at Burlington, Ohio, each of the three divisions of the median tripartite cyc appears to be supplied with a lens.

\section{DESCRIPTION OF PIAATES.}

$a^{1}$, antennulary nerve; $a^{2}$, antennary nerve; $c$, circum-oesophageal commissure; $m d^{d}$, mandibular nerve; $m x^{1}, m x^{2}$, first and second maxillary nerves; $n$, ventral chain; $W . S$., infraxsophageal ganglion; $O$, optic nerve; $S . G$., supracesophageal ganglion,

All figures were drawn with an Abbe camera from sections of Cyprisherricki.

Fig. I. Transverse section of budy in the region of the posterior portion of the midgut.

Fig. 2. Transverse section of median eye.

Fig. 3. Longitudinal section of circum-n:sophageal commissure.

Fig. 4. Transverse section through sensory organ at margin of mouth [fig. 7 A.]. Only the bases of the hairs appear in the section and look like teeth, but in adjoining sections the tips of the hairs can be demonstrated.

Fig. 5. Transverse section of the chitinous muscular support which lies immediately dorsad of the nervous clain. This is show in situ in fig. $\mathbf{I}$.

Fig. 6. Transwerse section of body in the region of the lateral diverticles of the midgut.

Fig. 7. Longitudinal section through the infracesophageal ganglion.

Fig. 8. Longitudinal section through the brain at the level of the origin of the circum-esophageal commissures.

Fig. 9. Median longitudinal section of the entire body.

Fig. Io. Transverse section of brain, through the origins of the optic and antennulary nerves.

Fig. II. Longitudinal section through a portion of ventral chain showing its intimate connection with the mesenteries. Seen in silu in fig. $9 \mathrm{~B}$. 
Journal of Comparative Neurology. Vol. III. PLATE III.
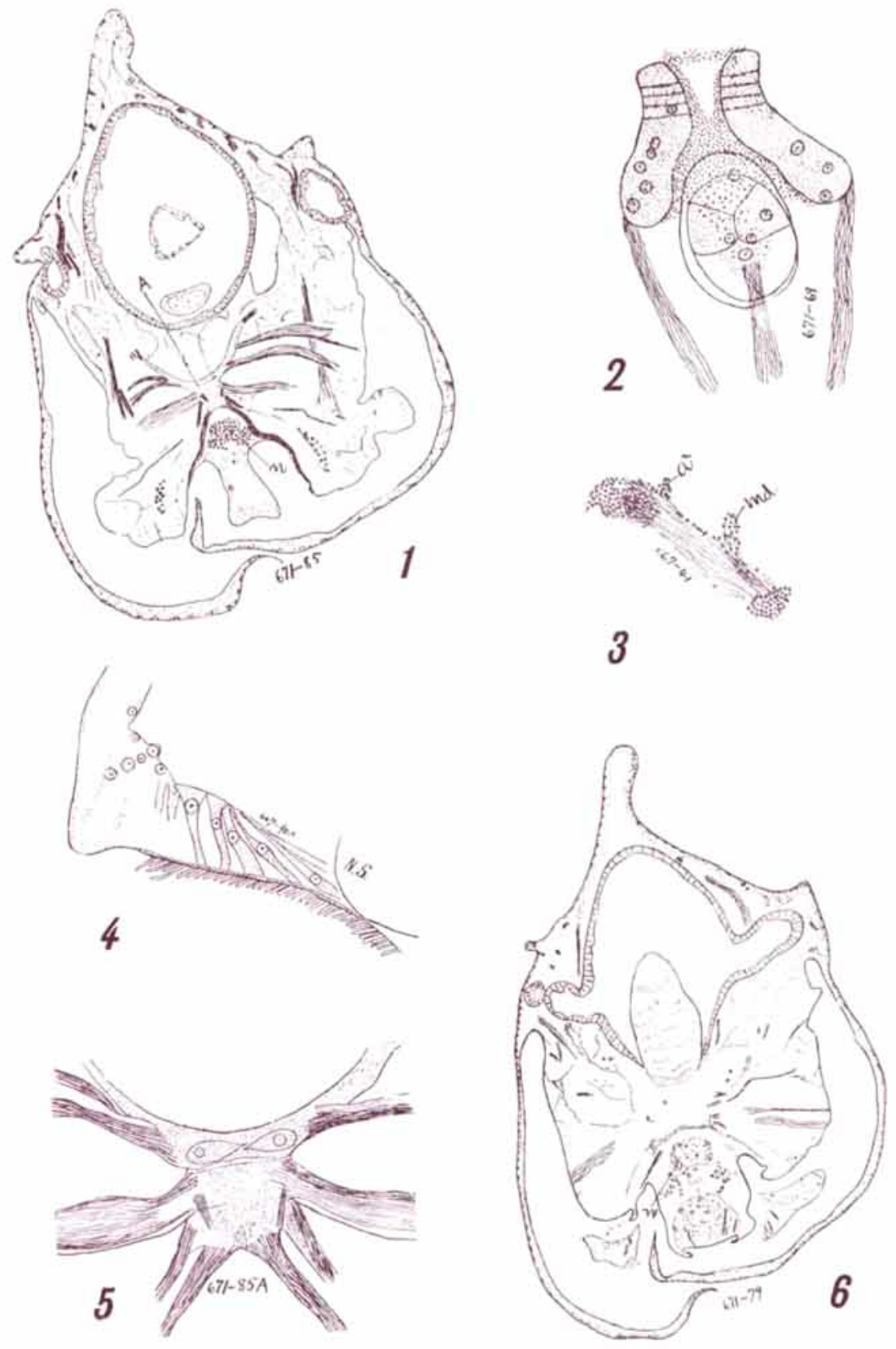
Journal of Comparative Neurology. Vol. III. PLATE IV
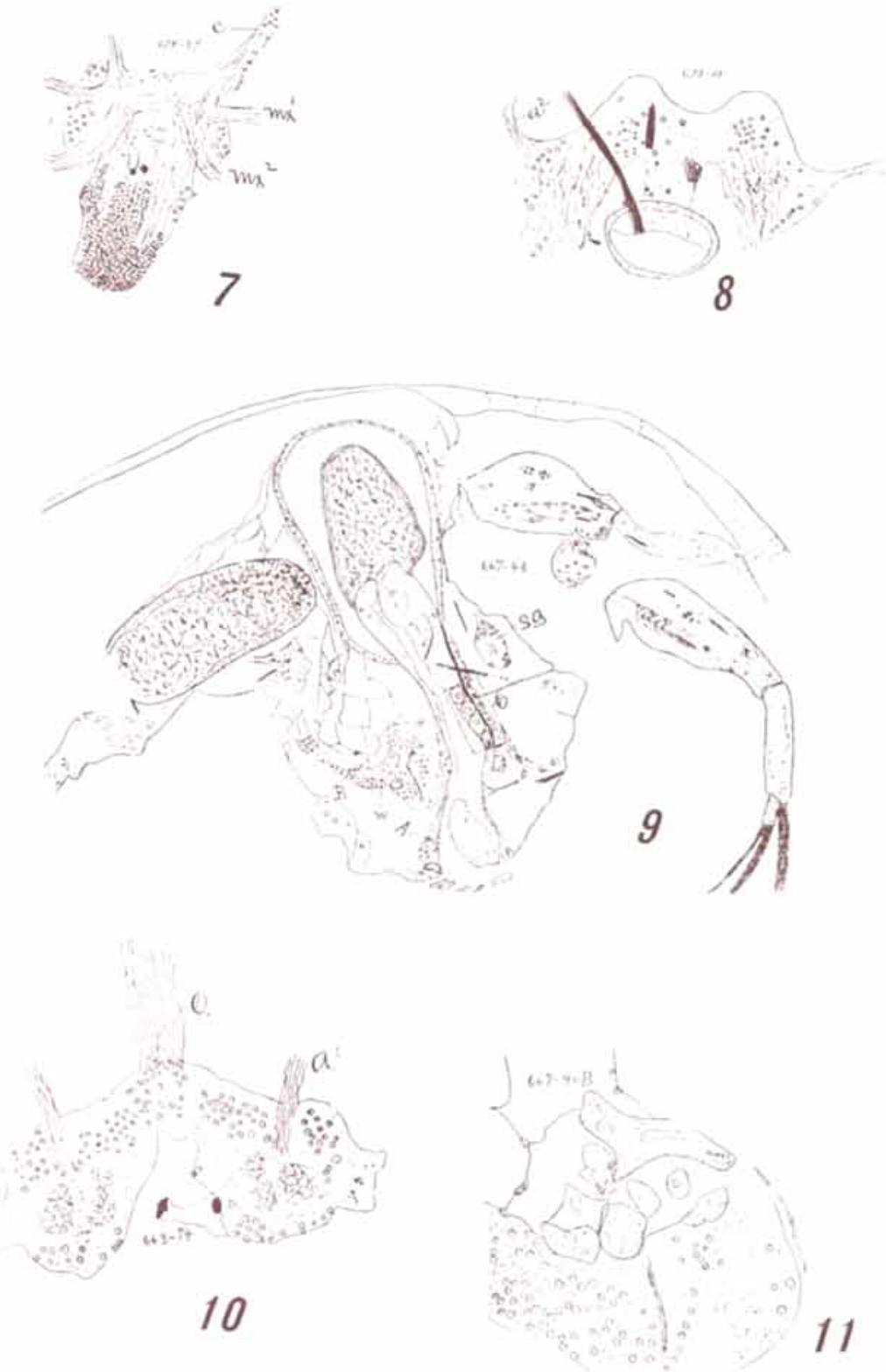